\title{
Memory aids, information artifacts and aging: medication-taking strategies
}

\author{
Claudio Henrique da Silva, \\ Carla Galvão Spinillo
}

\section{INTRODUCTION}

Access to health information is not only a necessity for patients but also their right as citizens. This need reflects the desire for autonomy and citizenship, directly related to empowerment of the citizen. Leite and Ventura say $(2011$, p. 5) that empowerment is 'the process by which those who hold power, in this case, health professionals, favor others (users) to acquire and use the necessary power (information empowerment) to make decisions that affect you or your life.' In addition, there is a practical need that relates to the correct use of medications. Waarde (2010) comments that it is practically impossible to take medicines without information.

Waarde (2010, p. 42) further states that "The aim of providing information about medicines to patients is clear: to enable patients to make decisions about medicine use and to enhance appropriate and effective use." In this sense, the patient needs to know the name of the medication, indication and purpose of the treatment, therapeutic regimen (dose, frequency, timing and duration of treatment) and how to administer the medication correctly. In addition, the elderly show concern about the adverse effects of medications (Zogg et al., 2012).

Some drug information is tightly controlled (Waarde, 2014) and made available through prescription, package insert and medication packaging. In Brazil the regulation is made by the Ministry of Health, through the National Agency of Sanitary Surveillance - ANVISA. Although subject to regulation, none of the three sources of information cited can meet the patient's information needs, and are ineffective in some respect (Waarde, 2013; Dixon-Woods, 2001).

The more drugs involved the greater the risks of adverse effects caused by the interaction between the drugs and also the non-adherence, especially among the elderly public. The elderly population is one of the most used medicines. The aging process brings with it a greater probability of diseases and chronic diseases. Bernal et al (2011, p. 304) commented that in Spain the elderly "consume between 25 and $50 \%$ of the prescribed drugs and account for $70 \%$ of total pharmaceutical expenditure." In Brazil, Cazarim and Araujo (2011) estimate that more than 
$80 \%$ of the elderly population takes at least one medication daily. Of these $80 \%$, it is estimated that $20 \%$ is polymedicated, that is, it takes more than 3 medications per day. (Simões, 2012)

However, for polymedicated elderly the concern about using medications properly extends also when remembering. Many studies argue that the process of remembering is anchored both in the biological brain and in the use of the external world as a hybrid process. People reshape the environment and use objects (artifacts) to extend the mind. Artifacts become a functional part of the human being (Heersmink, 2013; Kristiansson, 2011). This discussion becomes relevant insofar as people are considered to use internal and external memory aids for their daily activities to remember and make decisions. In this sense, drug information artifacts are essential for the elderly to achieve their therapeutic regimen.

In view of the above, what is intended to be discussed here is the use of the information artifacts used by the elderly as external memory aids in their multiple take medication strategies.

According to data from the last Demographic Census 2010 conducted by IBGE (BRASIL, 2012), there was an increase in the number of elderly people over 65 years old and a decrease in the number of people aged up to 20 years. In 2010, the percentage of elderly people increased to $7.4 \%$ of the Brazilian population, against $5.9 \%$ in 2000 and $4.8 \%$ in 1991. Simões (2012) comments that in 2008 there were 24.7 elderly people aged 65 or over for each group of 100 children from 0 to 14 years. The forecast for 2050 is for this picture to change dramatically. The expectation is that for every 100 children from 0 to 14 years old there will be 172.7 elderly people. The main factors that contribute to these results are the increase in quality of life and decrease in the fertility rate.

If, on the one hand, the quality of life has led to an increase in the life expectancy of the population, on the other hand, aging leads to a reduction in cognitive and motor skills, as well as greater coexistence with a large number of diseases. Elderly people are highly likely to have many diseases (Banning, 2008; Gellad et al, 2011) and are more susceptible to chronic diseases such as hypertension, diabetes, chronic lung disease, cardiovascular disease, stroke, and osteoarticular disease (CASSONI ET AL., 2014 ) leading them to take 3 or more medications to deal with this condition. In the case of chronic diseases, this condition may require long-term treatment (BANNING, 2008). Cazarim and Araujo (2011) point out that the greater coexistence of the elderly with chronic health problems makes them great users of health services as well as medicines.

Considering that patients in general suffer from various diseases such as diabetes, hypertension, among others, they are like to use several medicines at regular basis. Thus, trying to memorize schedules and dosages of various medications, 
as well as which ones should be taken at each moment, requires a great deal of cognitive effort, facilitating forgetting, confusing and changing medications and dosages. Take an example of an elderly person who takes 7 medicines under the following conditions: 4 medicines a day, 2 on alternate days (one day a medicine and the other day, another medicine) and another once a month. Of the four daily medications, 3 should be taken twice a day always 1 hour before or after a meal and 1 should be taken before bed. The two alternating medications should be taken soon after waking, also 1 hour before breakfast. Lastly, what should be taken once a month can be ingested at any time but not mixed with others. The scenery may seem surreal, but it is more common than it seems. The total of situations resulting from combinations of days, times, which medication, frequency of use, association with feeding moments make the therapeutic regimen very complex.

In this sense, in order to adhere properly to medical prescription, patients who take many medications, particularly the elderly, resort to external memory aids. Many of these aids involve the use of cognitive memory artifacts where visual elements such as color, size, position, spatial organization play an important role.

\section{INTERNAL/EXTERNAL MEMORY AIDS AND TAKE MEDICATION STRATEGIES}

Memory plays a fundamental role for the human species. Matos and Albuquerque $(2014$, p. 189) comment that "although it is more commonly related to past events, memory also implies the formation and accomplishment of future actions." This conception has a fundamental importance in the task of taking medicines, especially for polymedicated autonomous elderly, where this task is daily, continuous and not eventual.

Concerning the study of memory, there are approaches that classify memories according to: [1] their content (declarative or explicit, procedural or implicit), [2] their duration (short duration and long duration) their nature (storage or work) (Vianna et al, 2000). An alternative classification used by some researchers, based on the temporal direction of memory, divides long-term memory into retrospective memory and prospective memory (Kristiansson, 2011). This was the classification adopted for this discussion.

Retrospective memory refers to recalling information learned in the past, while prospective memory refers to reminiscing the execution of an action that will be developed in the future (Werlang, Argimon, Stein, 2008). Prospective memory involves the recovery of an action intention that is stored in long-term memory, requiring a retrospective recall. According to Matos and Albuquerque (2014, p. 190), prospective memory can be defined as "the ability to recall an 
action that is intended to be carried out in the future (intention), at a specific time or place, without any permanent instruction that reminds us of the action."

\section{Zogg et al (2012, p. 2) define prospective memory as}

the neurocognitive capacity to successfully form, maintain, and execute an intention at a particular point in the future in response to a specific cue.

Werlang, Argimon and Stein (2008, p. 97) comment that the correct use of a medicine requires a prospective component and a retrospective component of memory on the part of the patient: "The first component refers to the mnemonic rescue to perform an action future, while the second covers remembering the instructions regarding the therapeutic plan." According to Matos and Albuquerque (2014, p. 190), taking medications at specific times is an example of a prospective memory task. For the authors, in the "realization of an intention it is necessary to remember the appropriate moment or place for its realization (prospective component), but also its content (retrospective component)".

Insel et al (2013) comment that there are good evidences of the relationship between medication adherence and prospective memory. According to the authors, studies have shown that the advancement of age, which can bring deficits to the prospective memory, and the accomplishment of complex tasks, lead to the overload of working memory and also attention. As a result, they recommend encouraging the use of environmentally supported associative (relatively spared) recovery processes (ie with clues and external cues) rather than prospective memory processes that rely heavily on memory and other resources cognitive resources that usually suffer decline with age. In general, the authors comment that memory deficits and distractions from the daily rush affect memory processes, which may imply problems in recalling information and performing day-to-day activities (Insel et al, 2013).

In relation to the use of medicine by the elderly, Bouazzaoui et al (2010) state that the use of external memory strategies increases with age, while the use of internal memory strategies decreases. Their study suggests that elderly preferentially use external memory strategies to cope with the daily deterioration of their memory due to aging.

Internal and external memory strategies involve the use of internal and external memory aids. Kristiansson (2011, p. 11) comments on a categorization made by Intons-Peterson and Fournier where they divide the memory aids into internal, external and combination between the two. He presents a list with different types of internal and external aid, and a combination of the two (Table 1). 


\begin{tabular}{|c|c|}
\hline \multicolumn{2}{|l|}{ Internal } \\
\hline $\begin{array}{l}\text { Alphabetic } \\
\text { searching }\end{array}$ & $\begin{array}{l}\text { Going through the alphabet one letter at a time to see if it } \\
\text { sparks a memory. }\end{array}$ \\
\hline $\begin{array}{l}\text { Face-name } \\
\text { association }\end{array}$ & $\begin{array}{l}\text { Identifying a person's distinctive feature(s) and connecting the } \\
\text { person's name with the feature(s). }\end{array}$ \\
\hline Mental rehearsing & Mentally repeating to yourself what you want to remember. \\
\hline Mental retracing & $\begin{array}{l}\text { Thinking about something that happened before, or that may } \\
\text { happen, step by step, in an attempt to remember something. }\end{array}$ \\
\hline Method of loci & $\begin{array}{l}\text { Sometimes called the "mental walk technique" Using an } \\
\text { orderly arrangement of locations that you mentally associate } \\
\text { with the items you want to remember. Then, when you try } \\
\text { to remember, you "mentally walk" around the locations, } \\
\text { remembering each item you "put" in the location. }\end{array}$ \\
\hline No memory aid & Expecting memory to - pop up\| when needed. \\
\hline Peg-wordsystem & $\begin{array}{l}\text { Learning a series of number-word associations and then } \\
\text { forming a vivid image of what you want to remember along } \\
\text { with the number-word associations. For example, using the } \\
\text { "one is a bun, two is a shoe, three is a tree.. ?' technique, you } \\
\text { might imagine the first item you want to remember, say a } \\
\text { book, as sandwiched inside a gigantic hamburger bun. }\end{array}$ \\
\hline Rhymes & $\begin{array}{l}\text { Using rhymes about what you want to remember (like using } \\
\text { the rhyme, "Thirty days hath September... "' to remember the } \\
\text { number of days in the months). }\end{array}$ \\
\hline Story method & $\begin{array}{l}\text { Linking items or memories together by telling a story about } \\
\text { them, or by making sentences about them. }\end{array}$ \\
\hline $\begin{array}{l}\text { Tie to other life } \\
\text { events }\end{array}$ & $\begin{array}{l}\text { Remembering by associating with another life event (such as } \\
\text { "right after lunch" or "just before a history class"). }\end{array}$ \\
\hline \multicolumn{2}{|l|}{ External } \\
\hline $\begin{array}{l}\text { Asking someone } \\
\text { else to remind you }\end{array}$ & $\begin{array}{l}\text { Asking someone else to help you remember or asking if she or } \\
\text { he remembers. }\end{array}$ \\
\hline Calendar notes & $\begin{array}{l}\text { Writing down on a calendar, address book, etc., what you want } \\
\text { to remember. }\end{array}$ \\
\hline Photographs & Using pictures to remind you of something. \\
\hline $\begin{array}{l}\text { Putting something } \\
\text { in a special place }\end{array}$ & $\begin{array}{l}\text { Putting what you need to remember in a place where you will } \\
\text { be sure to see it. }\end{array}$ \\
\hline Reminder notes & $\begin{array}{l}\text { Writing down what you want to remember on a paper that } \\
\text { you can take with you. }\end{array}$ \\
\hline Timer & Using a mechanical, electrical or other timing device. \\
\hline Writing on hand & Writing what you want to remember on your hand. \\
\hline
\end{tabular}




\begin{tabular}{|l|l|}
\hline Combination & \multicolumn{2}{|l|}{$\begin{array}{l}\text { Saying something out loud as a way to remember (for example, } \\
\text { by telling another person or asking someone to repeat what you } \\
\text { have said). }\end{array}$} \\
\hline Trial technique & $\begin{array}{l}\text { Trying to write out or imagine part of the information to see if it } \\
\text { sparks a memory. }\end{array}$ \\
\hline
\end{tabular}

Table 1 - Memory aids classified in internal, external and combination of both. Source: Kristiansson (2011, p. 11)

Kristiansson (2011) comments that researchers have devoted more attention to internal memory aids than to external ones. He adds that internal aid is usually understood as normal memory operations and not as aids. They are usually studied in the laboratory, as opposed to external aids in which it is necessary to study people's daily lives. The author further comments that the role of memory aids is challenging and play an important role in our daily lives.

Considering the task of taking medicines, the complexity of the therapeutic regimen may require a greater number of memory strategies to take medications, as Boron, Rogers and Fisk (2013) point out. The authors present a list of options for what they call 'medication adherence strategies' (table 2). They provided these strategy definitions to participants in the survey of their research.

\begin{tabular}{|l|l|}
\hline Pill Caddy & $\begin{array}{l}\text { This method uses a pill caddy to help remember to take medical } \\
\text { products correctly. A pill caddy is a medication organizer or any other } \\
\text { device used to store medications (not in their original bottles). }\end{array}$ \\
\hline Association & $\begin{array}{l}\text { This method relies on using an activity or event to help you } \\
\text { remember to take medical products. For example you take your } \\
\text { medication every time you eat breakfast. Or you watch a certain TV } \\
\text { show, brush your teeth, or drink a glass of water every time you take } \\
\text { your medication. }\end{array}$ \\
\hline External & $\begin{array}{l}\text { This method uses physical reminders to remind you to take your } \\
\text { medical products. For example, you may set a wristwatch alarm to } \\
\text { go off when it is time to take a medication. Or you may place a sticky } \\
\text { note on the bathroom mirror to remind you to take a medication } \\
\text { before bed. NOTE: You should not base responses for this section on } \\
\text { your use of pill caddies. }\end{array}$ \\
\hline Location & $\begin{array}{l}\text { For this method medication is kept in a consistent location that may } \\
\text { or may not be visible. The location is used to help you remember } \\
\text { to take your medication. For example, you may always keep your } \\
\text { medical products in the kitchen pantry, in a medicine cabinet, or } \\
\text { in a medicine bag. Note: Pill caddy does not count as a location. } \\
\text { BUT, if you keep the pill caddy itself in a certain location to help you } \\
\text { remember to take medication correctly, please indicate below. }\end{array}$ \\
\hline
\end{tabular}




\begin{tabular}{|l|l|}
\hline Mental \\
Planning & $\begin{array}{l}\text { This method involves thinking ahead about when you will take your } \\
\text { medical product(s). For example, in the morning, you may plan when } \\
\text { the medication should be taken during that day. OR, throughout the } \\
\text { day, you many mentally repeat to remember the medication(s). The } \\
\text { planning makes it easier to remember to take the medication during } \\
\text { the day. }\end{array}$ \\
\hline Physical Pain & $\begin{array}{l}\text { The method uses how you physically feel. For example, you do } \\
\text { not think about your medication unless you feel pain or physical } \\
\text { discomfort. }\end{array}$ \\
\hline Visibility & $\begin{array}{l}\text { This method uses placing medical products in a highly visible place. } \\
\text { This is so you will notice the medications and be reminded to take } \\
\text { them. For example, you may place your medications on top of a } \\
\text { night stand, in the middle of the kitchen table, or next to a dinner } \\
\text { plate. NOTE: The visibility of this location is important, not the } \\
\text { location. }\end{array}$ \\
\hline
\end{tabular}

Table 2 - Description of Medication Adherence Strategies. Source: Boron, Rogers and Fisk (2013, p.13)

For polymedicated autonomous elderly, taking medication strategies involve internal and external memory aids, with the possible use of information artifacts. Werlang, Argimon and Stein (2008) cite some strategies that can be used to promote adherence to medications: packaging boxes, tablet diary, notes, calendars, pre-selection of medications which should be taken daily, calendars, use of alarm clock and mental schemes. In addition to the strategies listed by Boron, Rogers and Fisk (2013) and Werlang, Argimon and Stein (2008), many other strategies can be adopted/developed with the collaboration of health professionals, for example. The pharmacist elaborates a plan of care for a patient to prevent or solve problems in the use of medicines (BRASIL, 2014), especially when the patient is polymedicated.

\section{TAKE MEDICATION INFORMATION ARTIFACTS}

In order to define information artifacts, it becomes necessary to initially understand what artifacts are. Artifacts, in a broad sense, are "a physical object intentionally designed, made, and used for a particular purpose (HEERSMINK, 2013, p. 468). They are man-made technologies, therefore, anthropocentric and artificial.

Information artifacts may be considered, first of all, as cognitive artifacts because they are intentionally designed and made to aid human cognition (HEERSMINK, 2013). Their informational properties help in the accomplishment of 
cognitive tasks. From the point of view of information design can be called information design artifacts. Such artifacts are pieces of design whose purpose is to deliver a particular message according to the user's needs: direct visualization of data, summarization of complex contents or large volumes of information, immediate non-verbal messages, simplification of complex concepts, contextualization, among others (O'GRADY, O'GRADY, 2008), and can be physical or digital. O'Grady and O'Grady (2008) list various types of information artifacts that can be developed by information designers: calendars, timelines, graphs, diagrams and schemes, and others. It can then be deduced that the information artifact about medicine is a cognitive artifact, with cognitive function and with the specific objective of informing and orienting about the medicine and its use, developed or not by information designers.

From this definition, it can be seen that medication information artifacts can consist of a wide range of artifacts, where medical prescriptions, package inserts and medication packages are the most common examples. These artifacts are subject to regulation by government agencies and their development is subject to compliance with strict principles and rules. On the other hand, pill holders, calendars and smartphone applications are examples of information artifacts whose development is not subject to regulation. Medication information artifacts are also used to aid in the process of medication taking, constituting, in this sense, external memory aids.

\section{Regulated artifacts: Prescription, package leaflet and package of medication}

The regulated artifacts for medication usage are: Prescription, package leaflet and package of medication. The effectivess of these artifacts to communicate information on medicine usage has been questioned by several authors for their poor legibility and readability (Dixon-Woods, 2001; Spinillo, \& Waarde, 2013, Waarde, 2014), for example. Theses communications drawbacks of medicines regulated artifacts have a more negative effect on elderly patients due to health conditions and number of medicines taken.

Prescription is one of the first artifacts of information about medications that the patient has access to. It is subject to regulation regarding some information that must necessarily be present (Brazil, 2010).

As for visual elements, only aspects of readability (relating to textual elements) and color are required. Written by hand or printed, the prescription must present the information legibly (São Paulo, 1999; Brazil, 2010), which does not always occur. No other typographic question is required. The color is only used to differentiate the type of prescription. The white ones are used for medicines with or without red stripe. The blue ones are for medicines with a black stripe 
that can cause dependence (Brazil, 2010). Figure 1 exemplifies the two types of prescriptions.

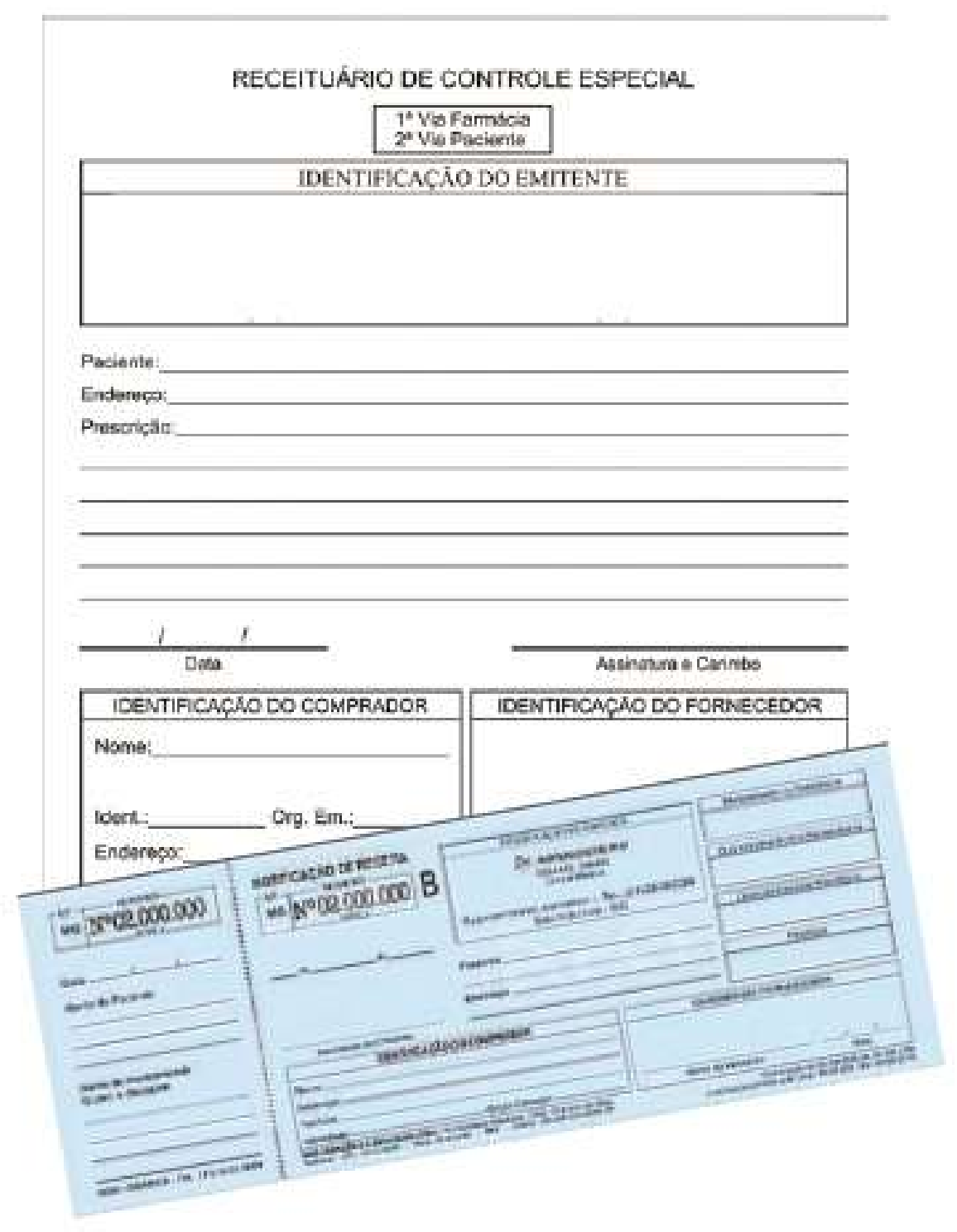

Figure 1 - Examples of white recipe and blue prescription (Brazil, 2010: 33)

Package leaflets and packaging of medication are the ones that suffer the most regulation in Brazil. However, Spinillo and Waarde (2013) comment on the deficiencies in the information visualization of medication use in Brazil and in 
Europe. The regulations, both in Brazil and in Europe, present difficulties for the development of these artifacts due to a certain lack of design features, for example, requiring a certain font size without indicating which font should be used (Waarde, 2014).

In Brazil, the package leaflets are eminently textual. Some characteristics such as size, font type, readability are required by current regulations. However, the package leaflets may also present pictures (illustrations and pictograms) in order to guide the patient about the use of the medication. Figure 2 shows an example of package insert.

\begin{tabular}{|c|}
\hline Medicamento Anvisa \\
\hline Paracetamol \\
\hline 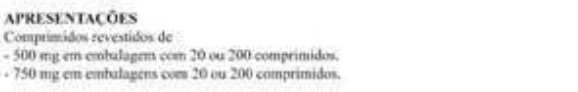 \\
\hline $\begin{array}{l}\text { TSOORLL. } \\
\text { tSO ADLLTO ACAMADE } 12 \text { ANOS }\end{array}$ \\
\hline 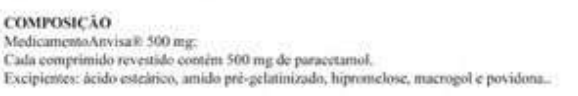 \\
\hline 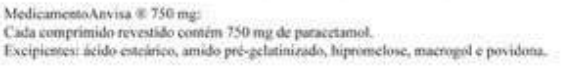 \\
\hline 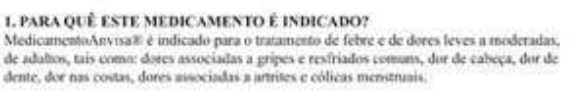 \\
\hline 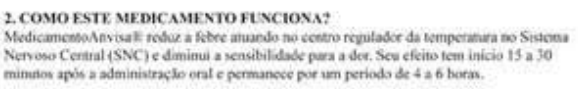 \\
\hline 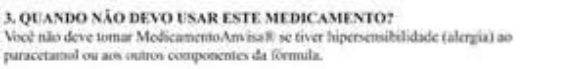 \\
\hline 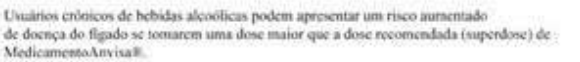 \\
\hline
\end{tabular}

4. OOLE DEVO SABER ANTES DE UTILIZAR ESTE MEDICANFVTO

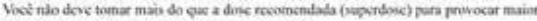

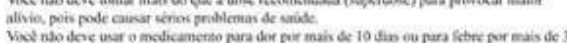

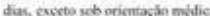

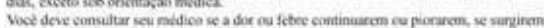

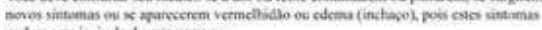
podem set siniè de doencos graves.

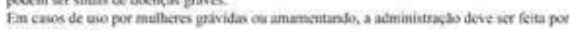
periodos cuntos

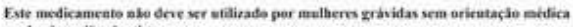
en de cirurgialo-deativta.

Atrecalo diabetices cate medicamento ceotém SACAROSE.

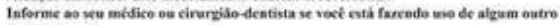
medicamesto.

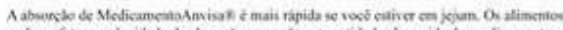
podem afctar a velocidade da ahweecjo, mas nso a quantidade alwoverida do modicamento

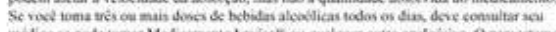

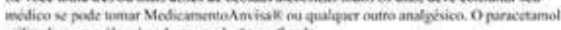
wilizado cues o ilceol pode causur lende bo fledo.

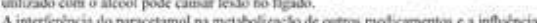
dosies medicamenton ma aclo e na toxicidade do poracetamet nabo So nekvaniex

Naso enc outre prodeto eque cuntenta paractamol

5. ONDE, COMO E, POR OUANTO TEMIPO ROSSO GUARDAR ESTE

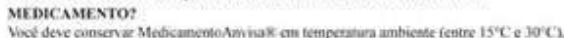
protegibla da lure ets umidale.

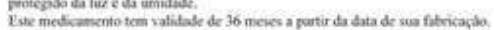

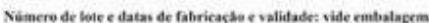

Nie use medicameate cem prate de validade veacido.

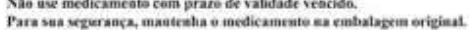

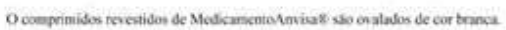

Anter de warar, obuerve o auperto do medicamento

Caso vocét olverver aterama medanca no mpects de medicamesto que ainda eseja no

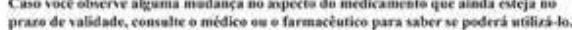
Todo medicamento deve ser mantido fora do alcance das criancas.

Figure 2 - Example of medication package leaflet. Source: http://www.blog.saude. gov.br/index.php/35211-bula-e-essencial-para-orientar-o-consumidor-sobre-uso-seguro-de-remedios

Packaging, on the other hand, uses with more emphasis other elements besides the text. Figure 3 shows the general characteristics of an external package of medication required by Anvisa. 


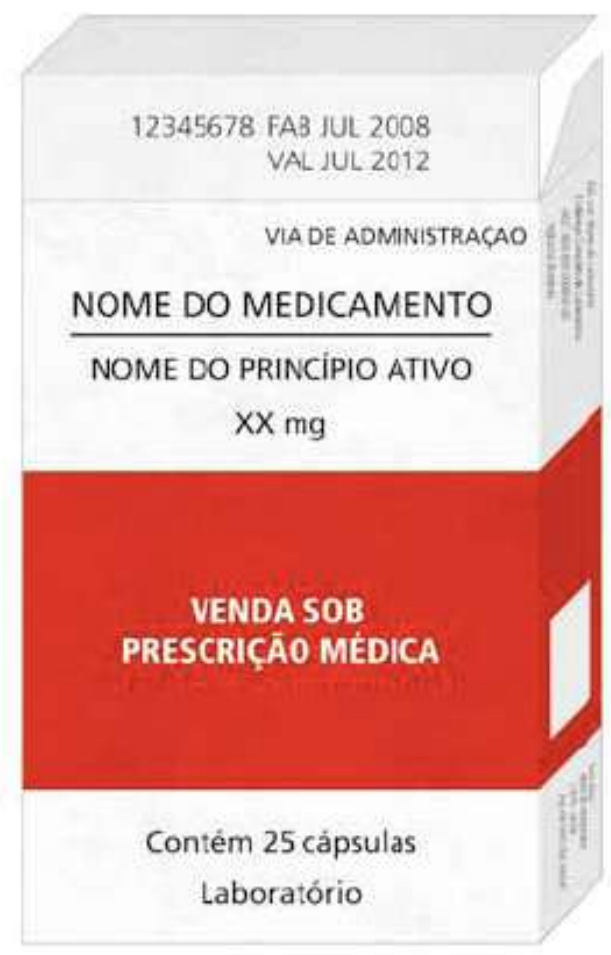

Figure 3 - External package of medication: general characteristics. Source: BRAZIL (2010, p. 19)

The medication in Brazil are classified for sale as Prescription-Free Medications (Medicamentos Isentos de Prescrição - MIP) and Prescription Medications (Medicamentos de Venda sob Prescrição). The latter is divided into two groups: no prescription retention and with prescription retention. The differentiation is made in the packaging by means of strips with specific colors and also with texts SALES UNDER MEDICAL PRESCRIPTION and SALES UNDER MEDICAL PRESCRIPTION I CAN ONLY BE SOLD WITH PRESCRIPTION. Figure 4 shows the distinctions of stripe for application in the packages according to the medicines. 


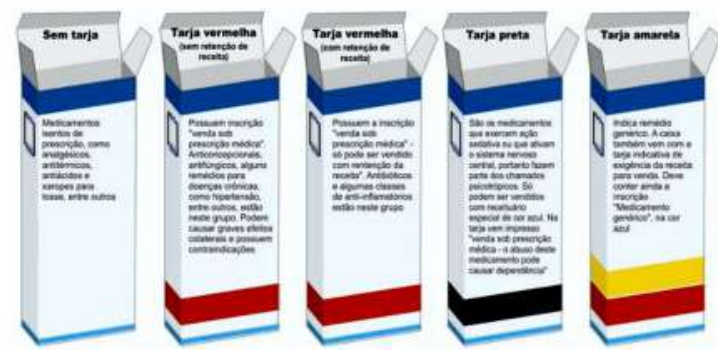

Figure 4 - Application of marking on medication packaging. From left to right: No stripe - Prescription-Free Medications; Red stripe - Prescription Medications (have the inscription "SALES UNDER MEDICAL PRESCRIPTION" or "SALES UNDER MEDICAL PRESCRIPTION WITH PRESCRIPTION RETENTION"; Black Medications (have the inscription "SALES UNDER MEDICAL PRESCRIPTION - ABUSE OF THIS MEDICINE CAN CAUSE ADDICTION); Yellow stripe (indicates a generic medicine - may be accompanied by another stripe). Adapted from: https://familia.com.br/5587/how-to-think-the-treatments-instruments

The packages must comply with the standardized identification and described in the Visual Identification Manual for Medicinal Packaging (Brazil, 2014b). The manual standardizes packaging of medication with commercial and generic names. Figures 5 illustrate one of the guidelines in the manual.

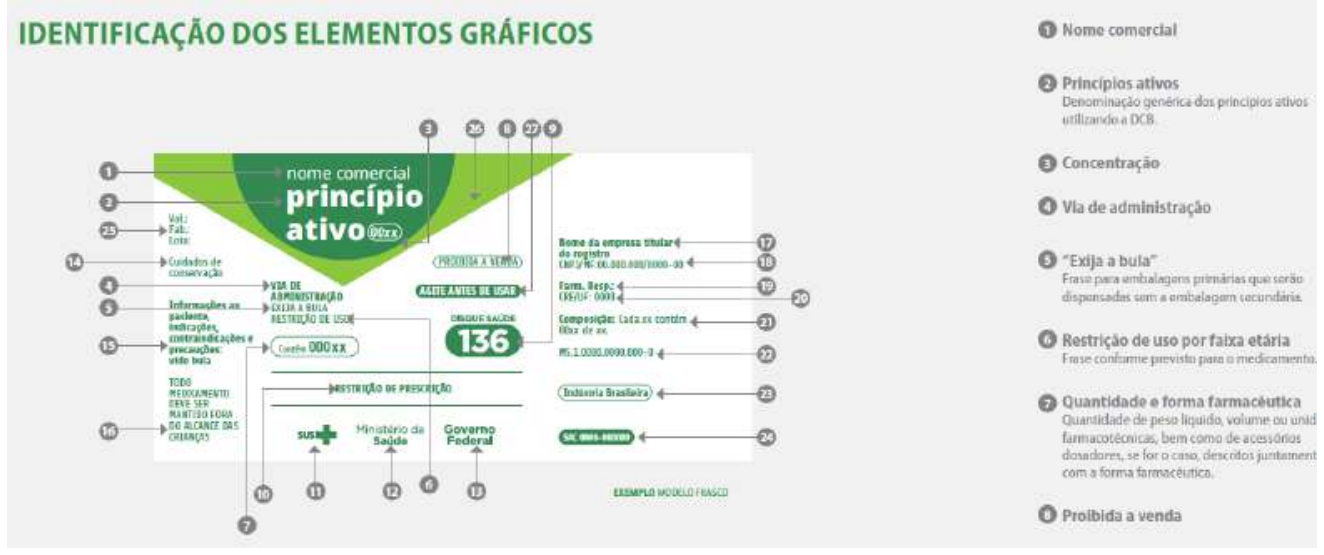

Figure 5 - Part of Identification of graphic elements guidelines. Source: BRAZIL (2014b, p. 16-17) 
In general, it can be observed that the use of color as a distinctive element is limited to differentiating the types of medicines (reference, generic, intended for SUS), one drug industry of the other (they can opt for other than background white) and the degree of control (by the presence and color of the stripe). Neither color nor typography offers information to distinguish one drug from another, or the concentration of the drug (125mg or $500 \mathrm{mg}$ tablets). Figure 6 exemplifies a medicament with different concentrations but with substantially identical packaging.

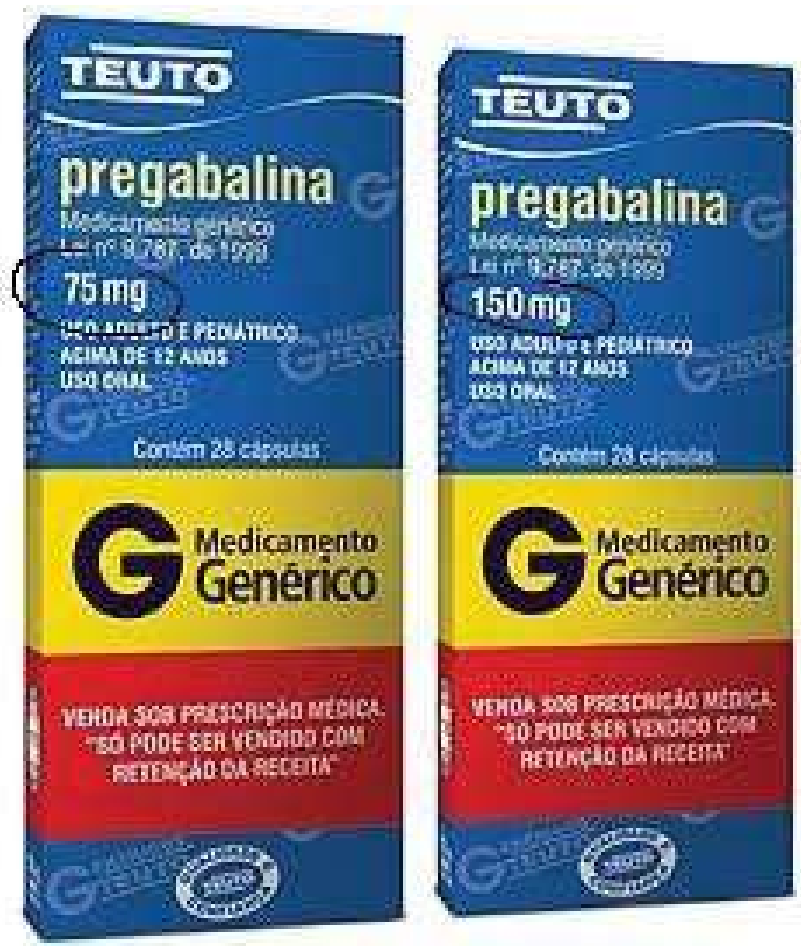

Figure Figure 6 - Packaging of a medicine with difference in concentration Source: https://www.revistafatorbrasil.com.br/imagens/fotos2/teuto_pregabalina

Non regulated medicine information artifacts

As mentioned earlier, some information about medicines is not subject to regulation, and the artifacts that carry them are not. From pill holder to smartphone apps, there are myriad of informational artifacts about medicines being 
used by people who take some kind of medicine. The literature on these artifacts is sparse and scattered. Many are mentioned in studies, but are not studied from the point of view of information design.

The pill holder is one of the most common. There are hundreds of models available in the market, varying in shape, number of compartments and functionalities (lock, alarm, among others). Some models have been selected as examples.

The model of Figure 7 has 7 compartments, identified by the days of the week and allows to organize medications for a time of day. The model of Figure 8 has 14 compartments, allowing to arrange medicines for two times of the day.

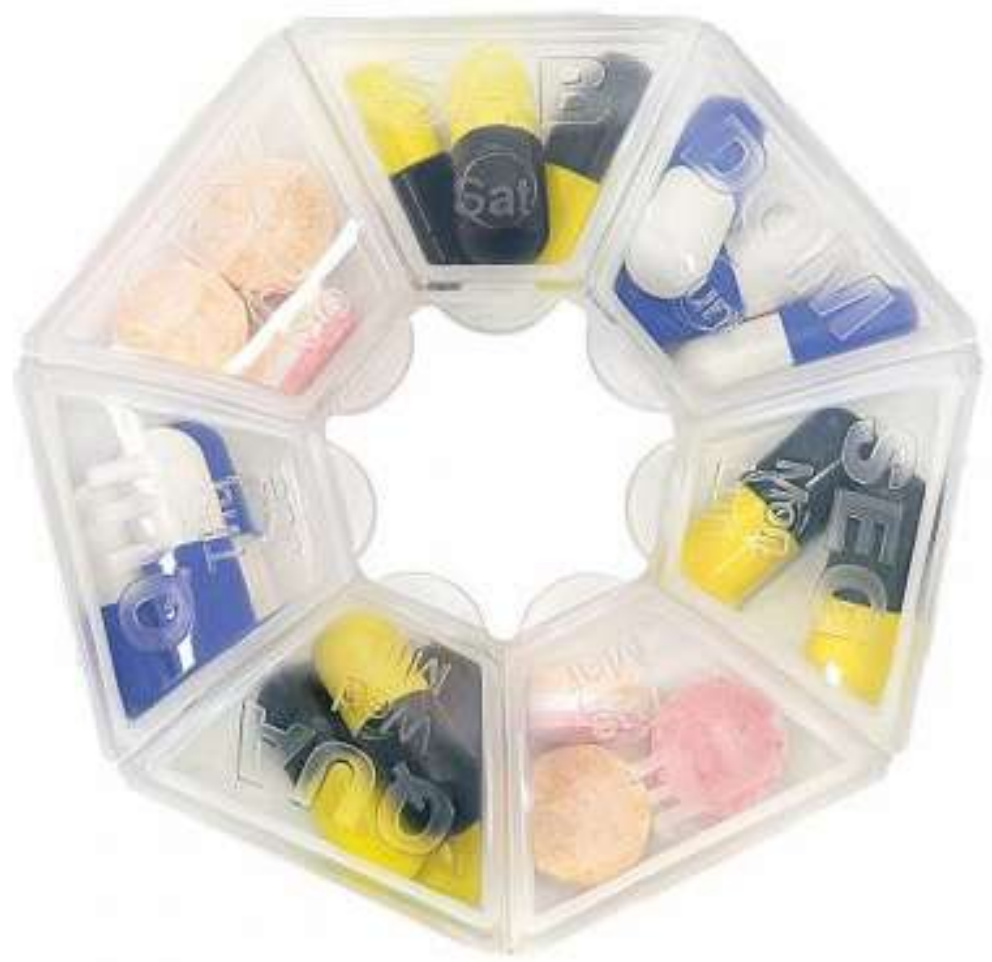

Figure 7 - 7-compartment pill holder. Source: http://i111.twenga.com/saude-beauty/popula/plasutil-porta-comprimidos-tp_7182541201700943624f.jpg 


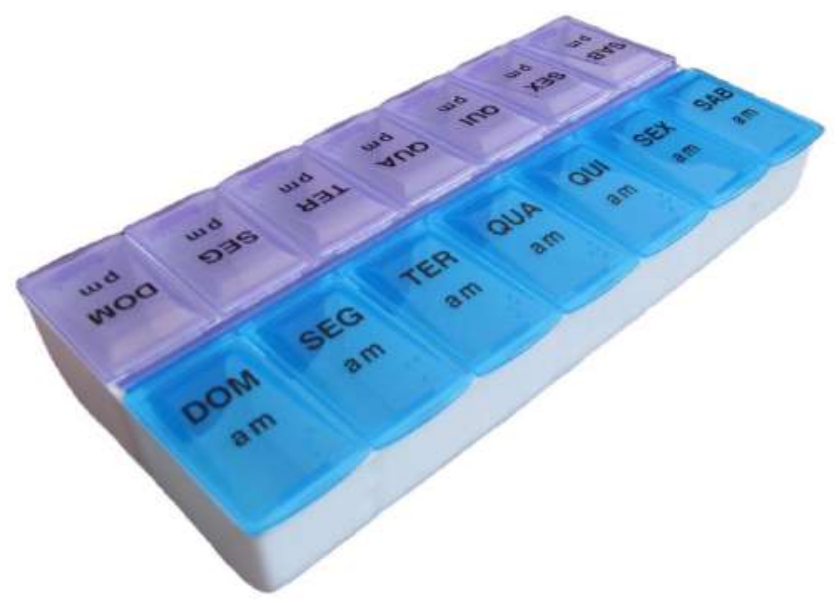

Figure 8 - 14 compartments pill holder. Source: https://http2.mlstatic.com/20-porta-comprimidos-organizador-diario-de-medios-D_NQ_NP_22903-MLB20237765380_022015-F.jpg

The models of figures 9 and 10 allow to organize the medicines by 4 schedules during the day. The model of Figure 9 has 28 compartments and a locking system that only releases the compartment where the drugs are currently being taken.

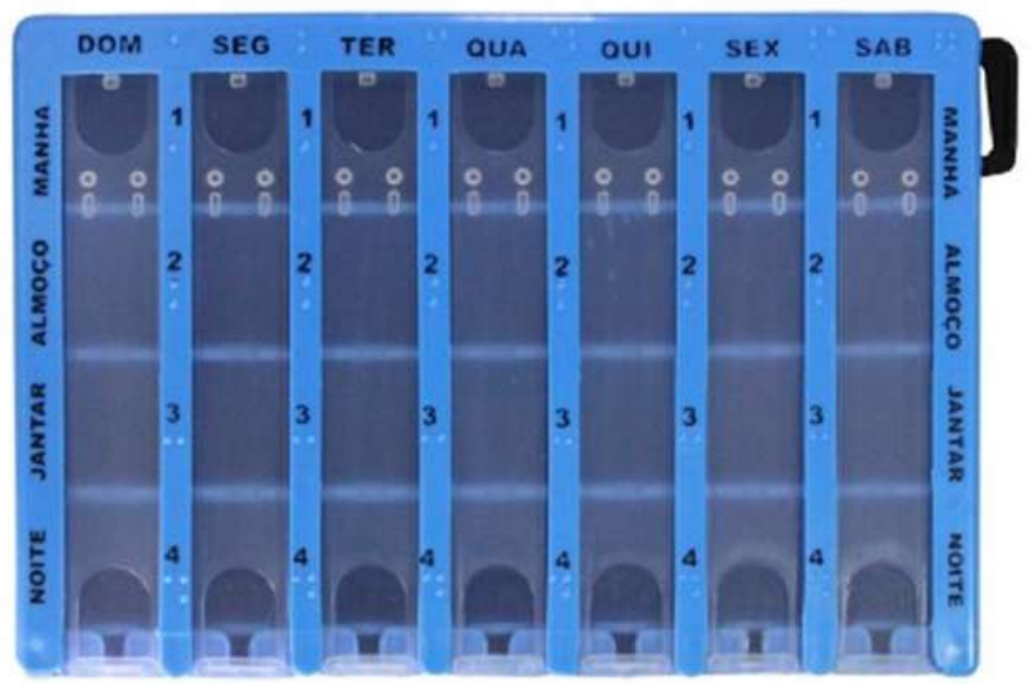

Figure 9 - Locked pill holder. Source: http://www.lojadoavo.com.br/p/395/porta+rep air+time+contact+with+travel+of+safety 
The model in Figure 10 also has 28 compartments, but is made up of 7 boxes - one for each day of the week - and a structure for storing them. The box below is that of the day and, once unoccupied, is replenished and placed on top of the stand. In addition, the box of the day can be carried individually by the person.

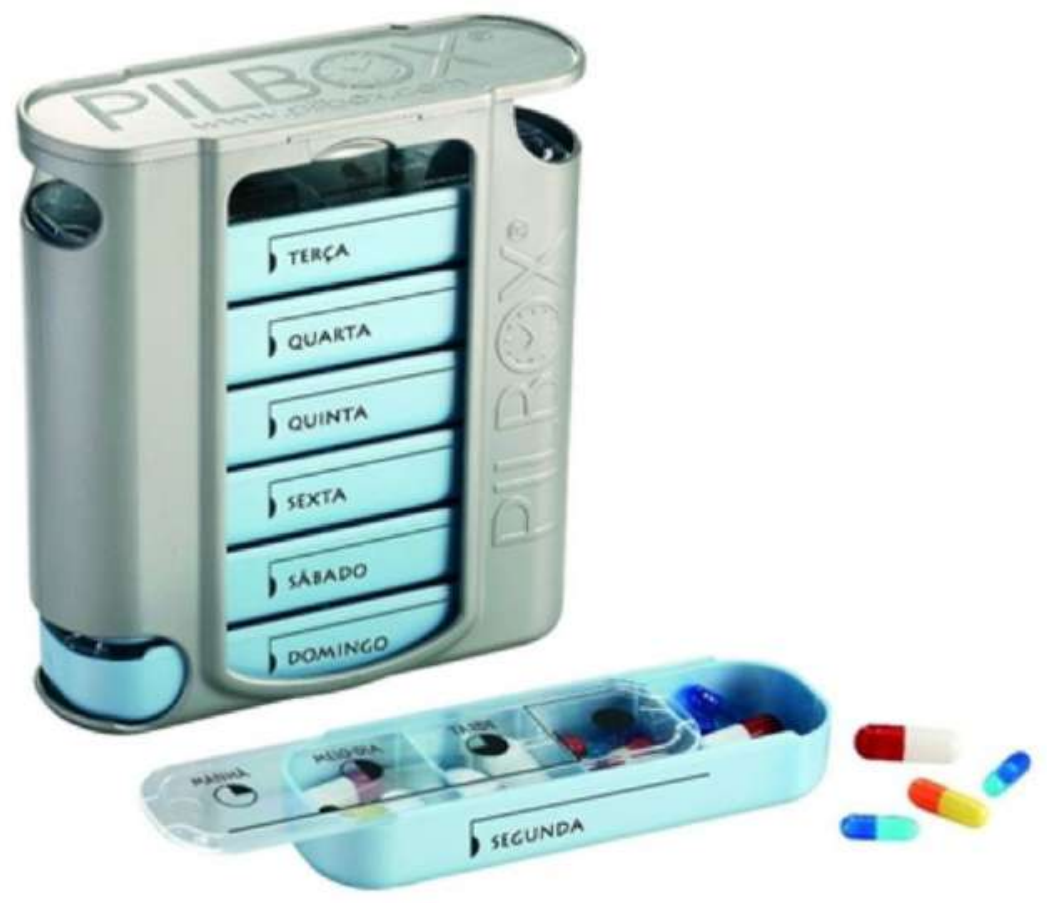

Figure 10 - Pill holder with individual box. Source: https://shoppub.s3.amazonaws. com/primecirurgica/media/cache/f6/db/f6dba5b642f48eb686f880477185be0a. jpg

The use of smartphones makes it possible to take medicine using apps. Figure 11 shows some screens of the Medisafe app. Once the medications, their schedules and dosages are scheduled, the app will notify the person and continue the alert until you click on the options 'skip', 'reschedule' or 'take'. The medications are presented visually as if they were in a divided pillbox at four times a day 

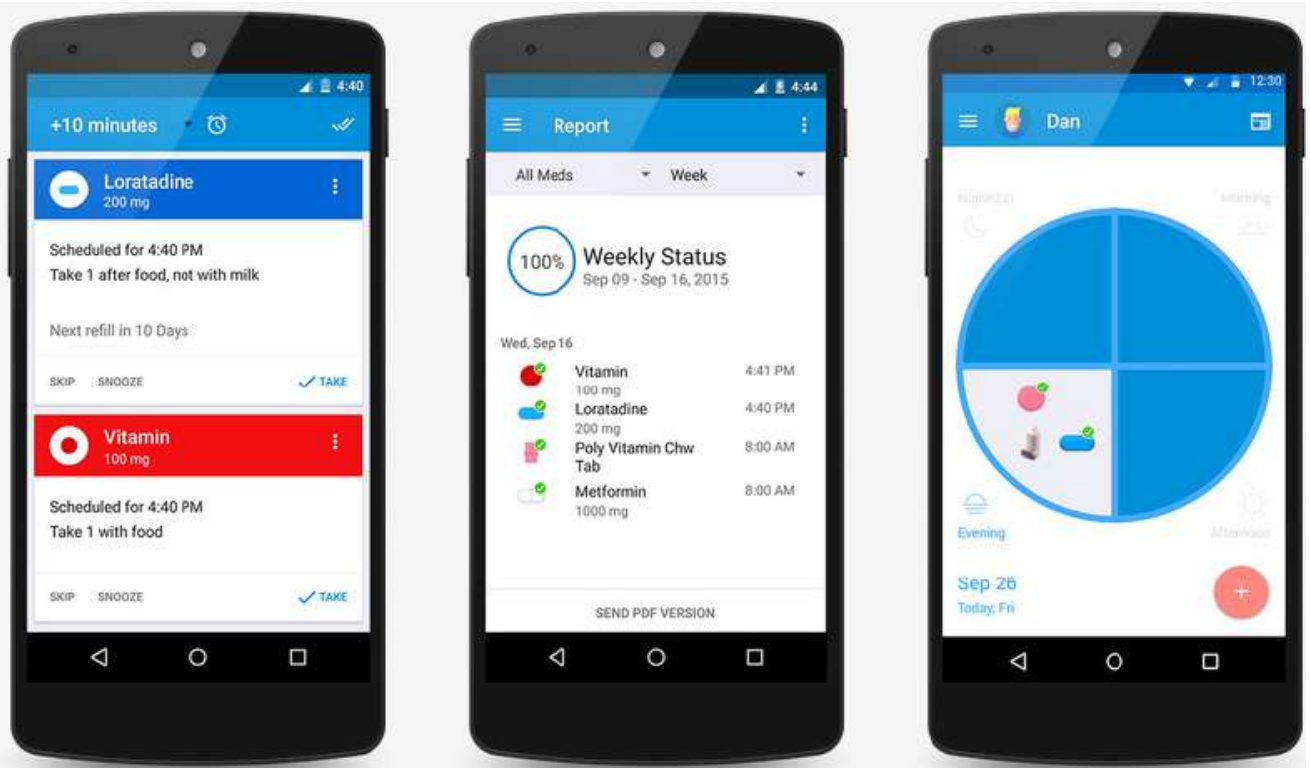

Figure 11 - Medisafe app screens. Source: https://www.android-apps.us/medisafe-meds-pill-reminder-app/

Recently the company launched Medisafe iConnect (Figure 12) which allows the integration of the app with medicine bottle with electronic lid and also with a compressed port. Figure 13 exemplifies the process of integrating the app with the medicine bottle christened iCap.

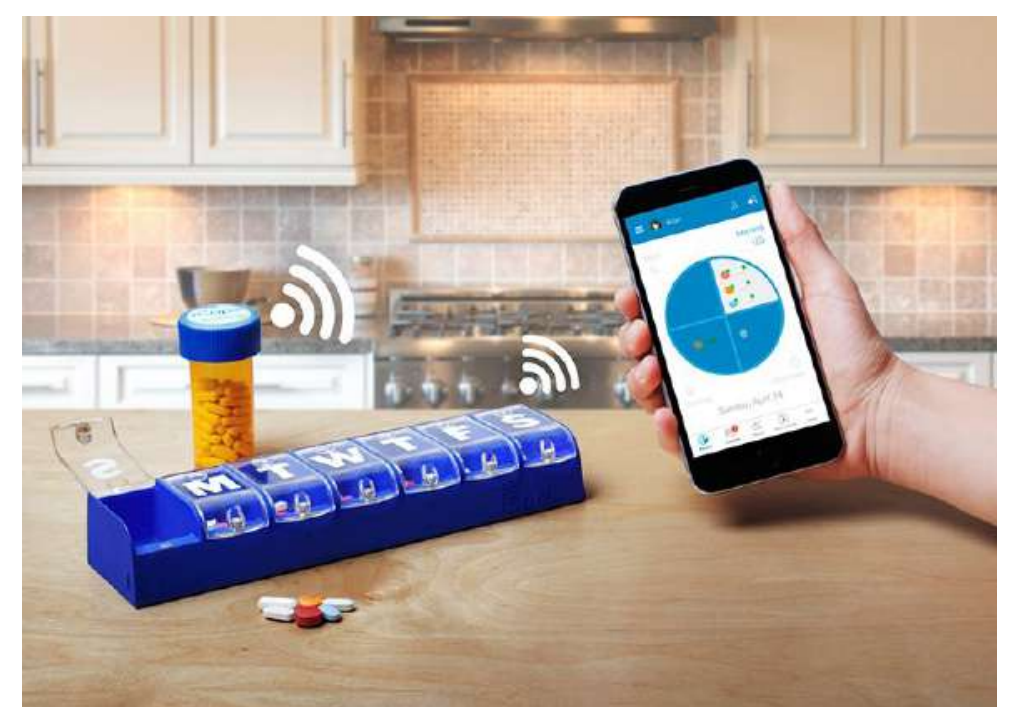

Figure 12 - Medisafe iConnect. Source: https://www.medgadget.com/2016/04/ medisafe-iconnect-an-affordable-smart-pill-management-system.html 


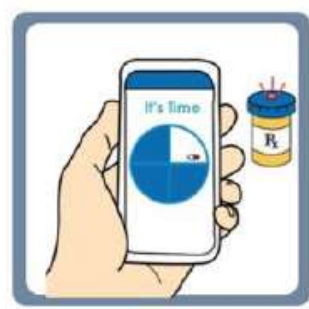

Be notified

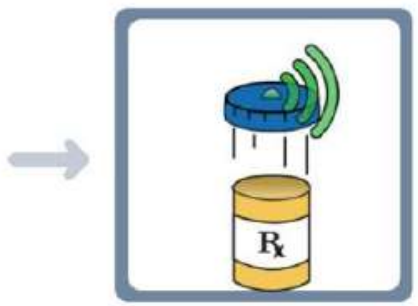

Take your medication

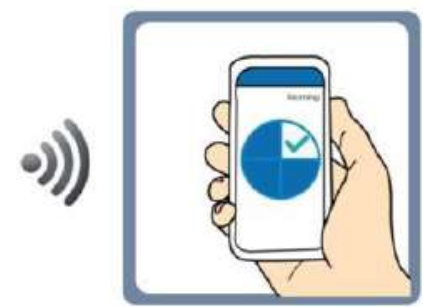

Be synchronized with the medsafe application

Figure 13 - Medisafe iConnect - integration app x bottle. Source: https://canaltech. com.br/noticia/gadgets/startup-cria-dispositivos-para-auxiliar-a-rotina-de-quem-toma-medicamentos-74757/

Health professionals have also been dedicated to creating information artifacts to assist patients in taking their medications. Among the artifacts with the highest degree of elaboration can be mentioned the Electronic System for Custom Use and Controlled Medication (SUPERMED). The goal of its development was 'to contribute to adherence to medication treatment and to the safety of elderly patients.' (Vieira, 2013, p.44) This is an alarm organizer to remind patients of the correct time (Figure 14).

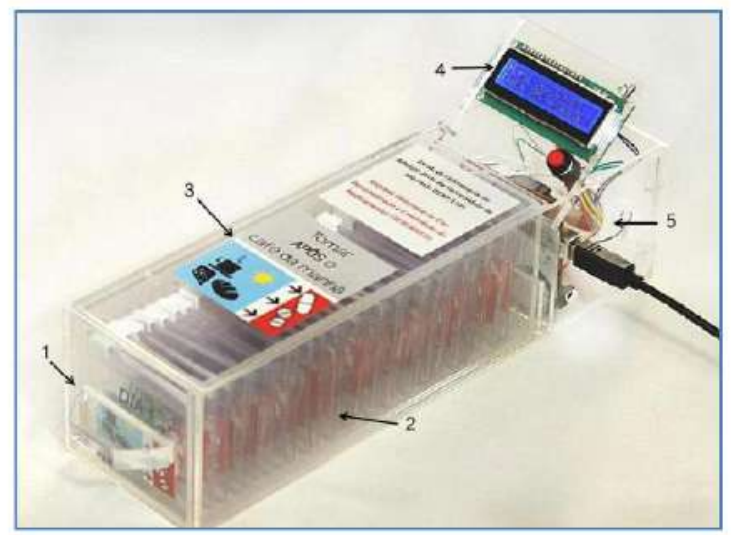

1 - Medicine organizer box; 2 - Sachet of medicines; 3 - Labels with information for correct use; 4 - Alarm clock; 5 - Electronic system

Figure 14 - SUPERMED - Source: VIEIRA (2013, p. 45) 
The medications are separated and placed in sachets (Figure 15) with identification stating the day, time and dosage. Time and dosage are represented by the use of images (Figure 16).

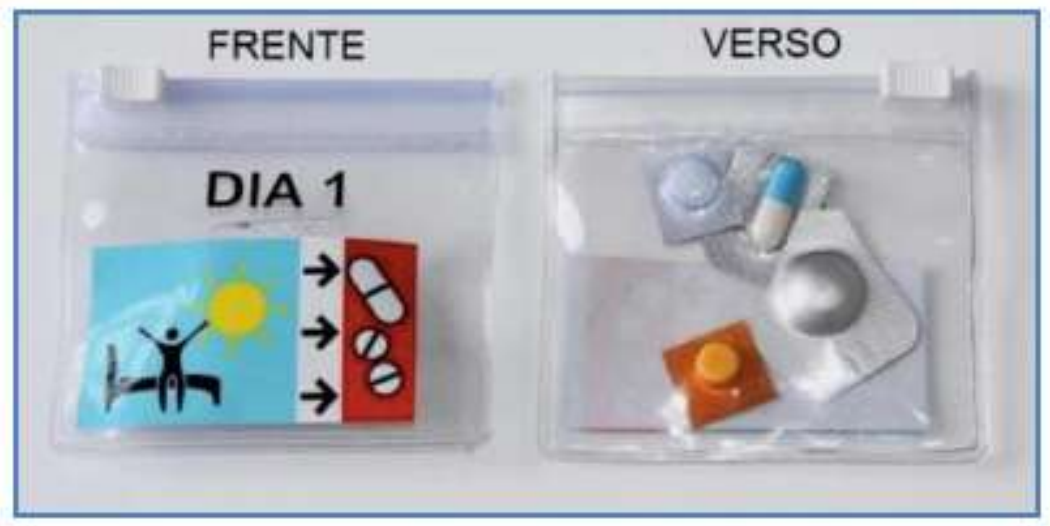

Figure 15 - Medicated sachet. Source: VIEIRA (2013, p. 46)
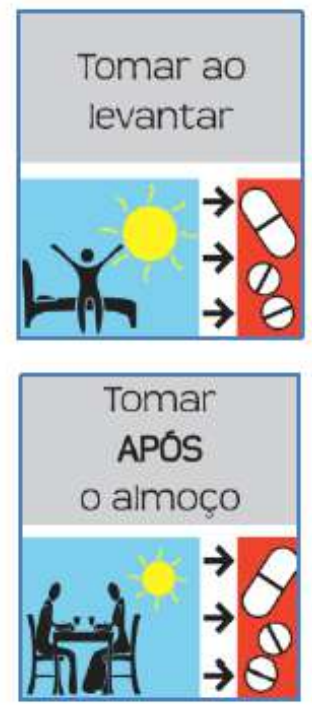
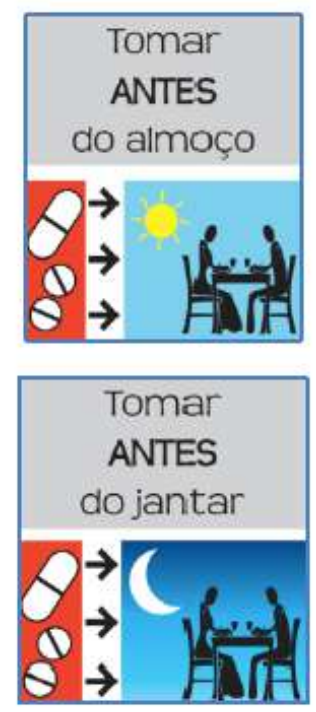
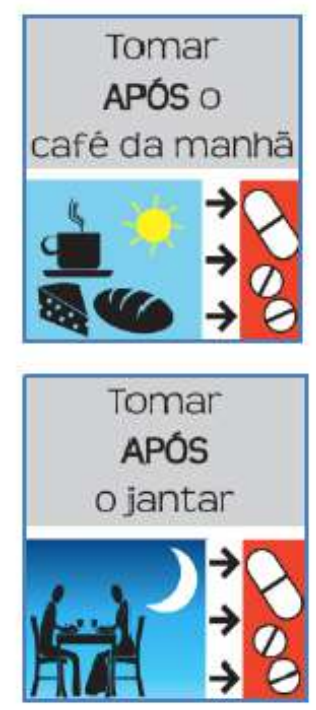
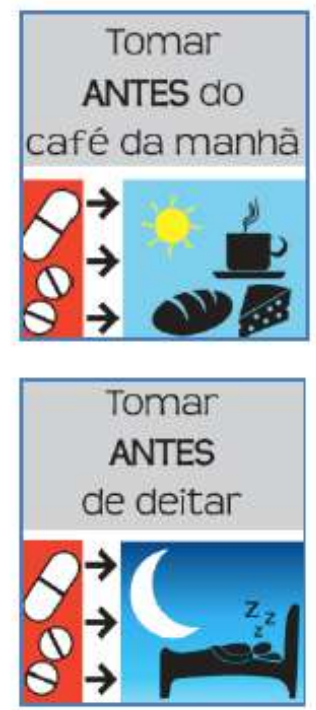

Figure 16 - Labels with correct information for medication use. From left to right (up): "Take it as soon as you wake up", "Take before lunch", "Take after breakfast", "Take before breakfast". From left to right (bottom): "Take after lunch", "Take before dinner", "Take after dinner", "Take before bedtime". Source: VIEIRA (2013, p. 46).

Figures 17 and 18 present SUPERMED prepared for various moments of the day. 


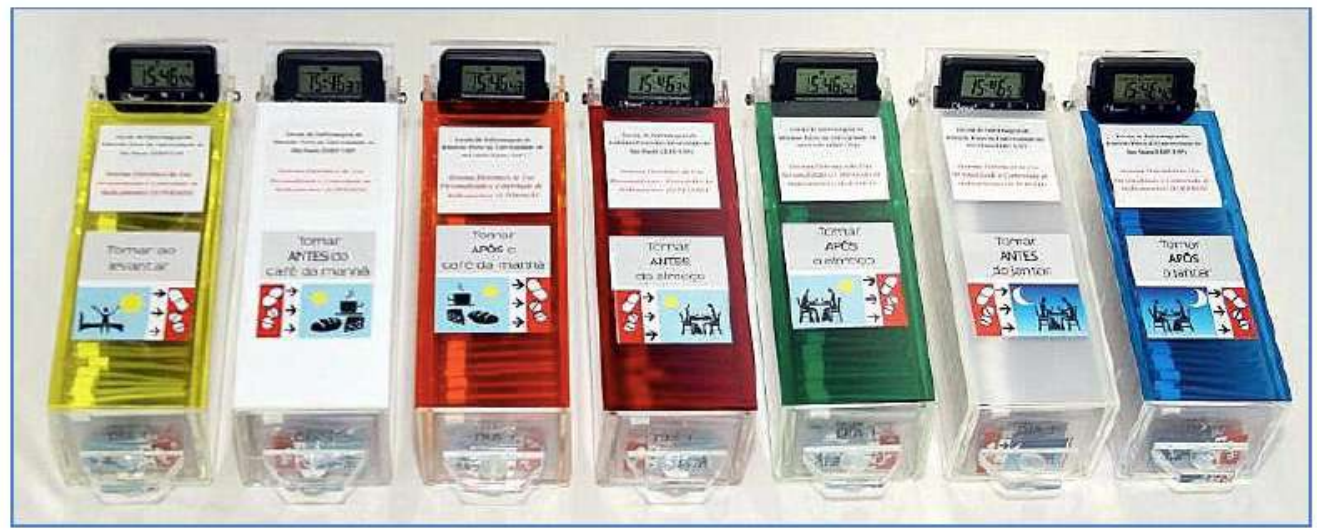

Figure 17 - SUPERMED prepared for patients with seven different moments to take their medication. Source: VIEIRA (2013, p. 48)

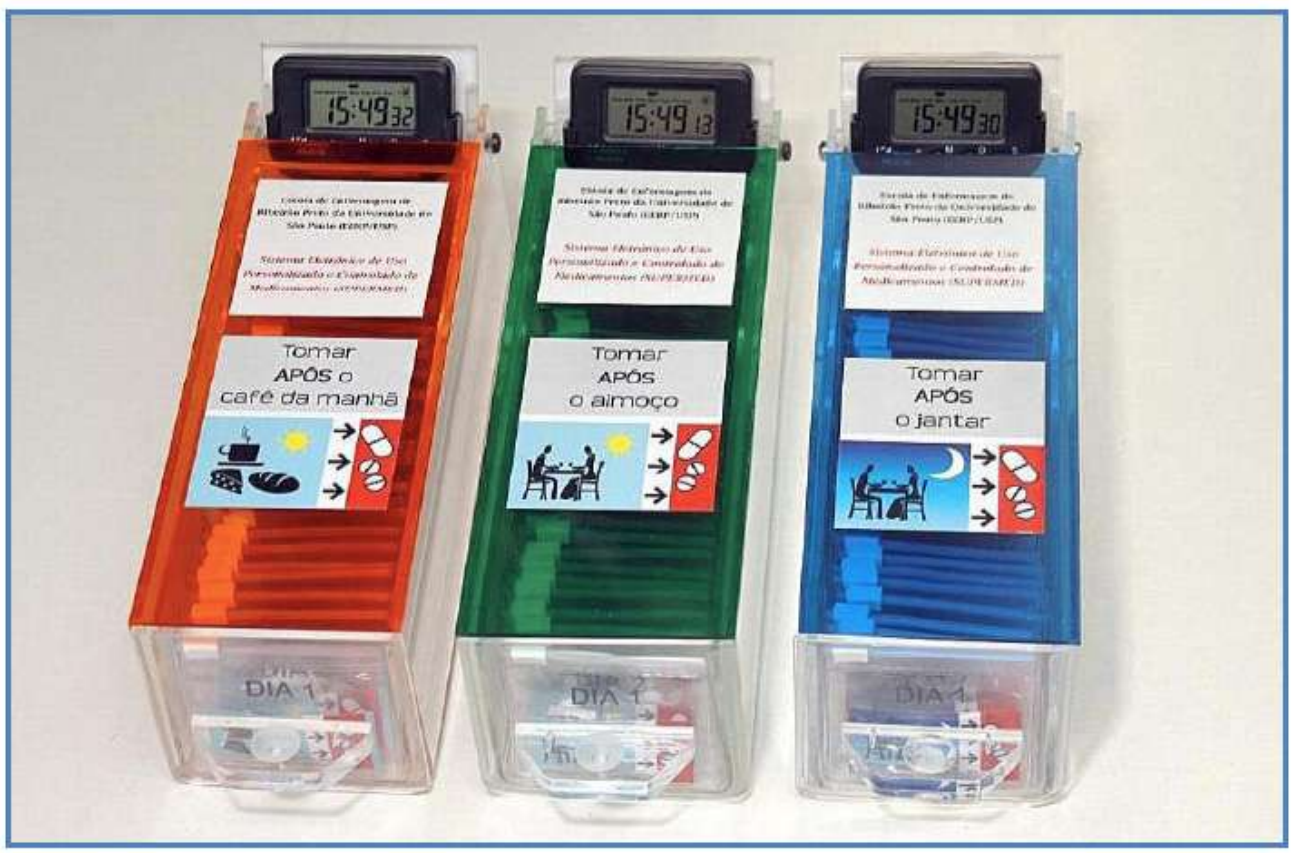

Figure 18 - SUPERMED prepared for patient with three different moments to take their medications. Source: VIEIRA (2013, p. 50)

Regarding aid provided by pharmacists to elderly patients, a common artifact is organized in the form of time tables whether using images associated with events of the day or text only. Figures 19 and 20 are examples of such sheets. 


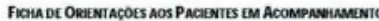

ACONSEUHAMENTO aO PaCient:

Nome:

Dota:

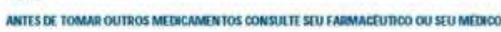

PERTOOOS DODIA
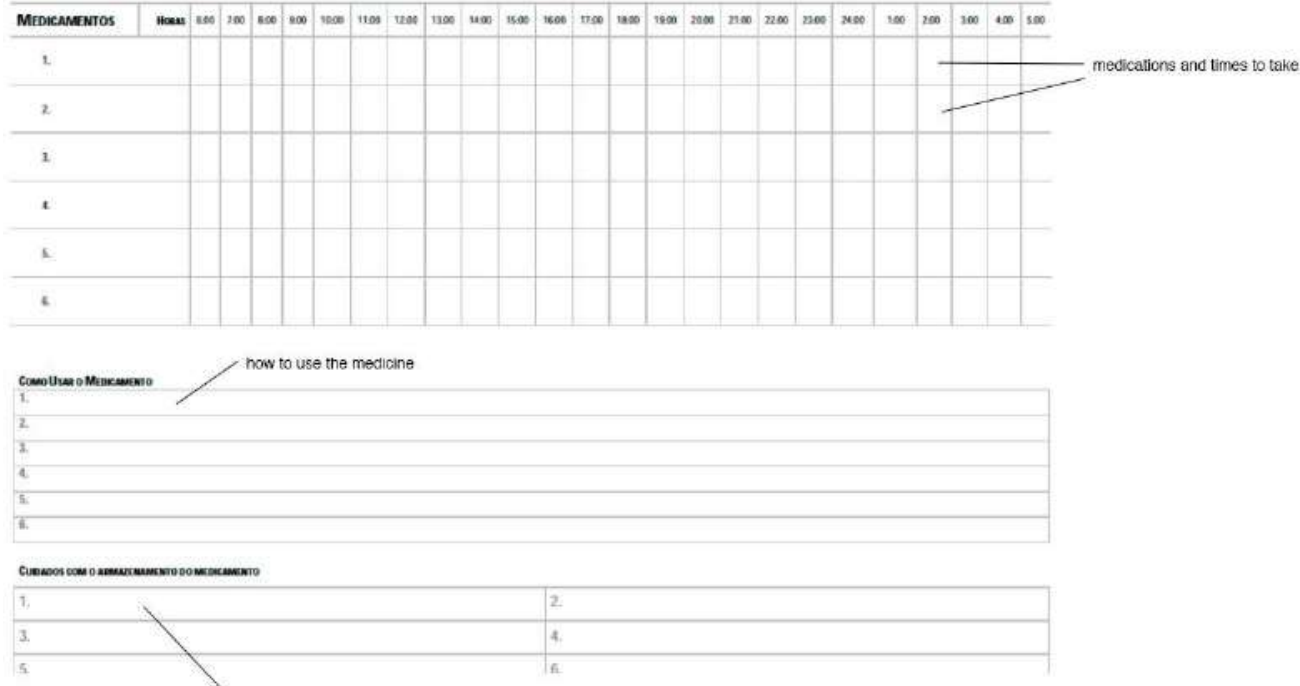

care with storage of medicines

Figure 19 - Guidance sheet for follow-up patients. Source: MINAS GERAIS (2009, p. 87)

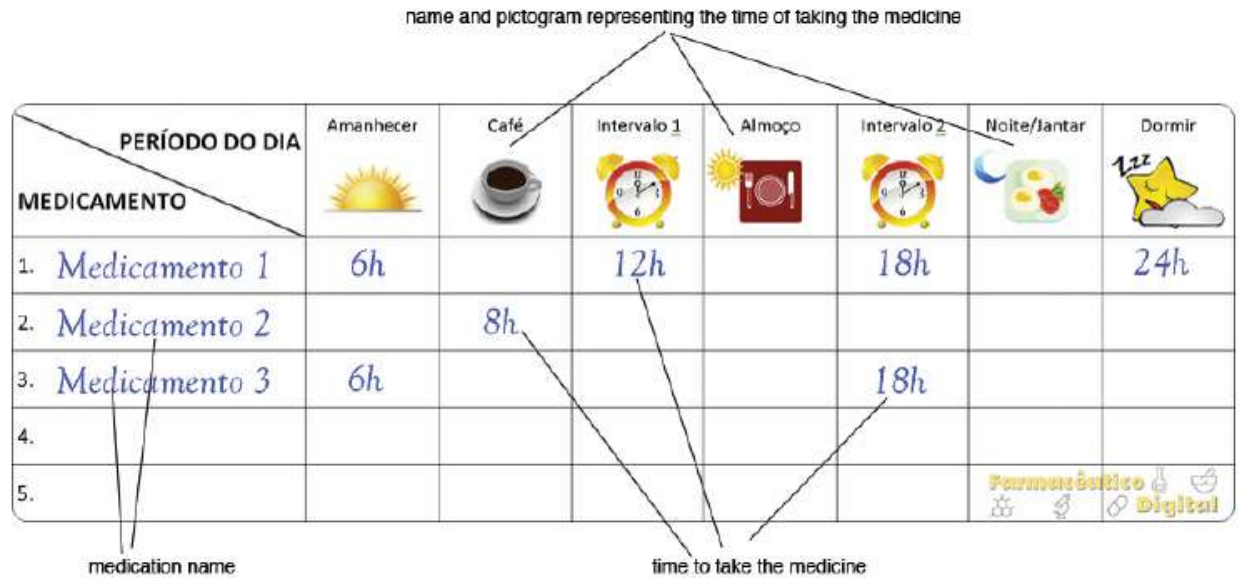

Figure 20 - Example of guidance sheet for patients on the use of their medications. Source: https://iO.wp.com/farmaceuticodigital.com/wp-content/uploads/2016/05/ tabela-horario-medicamentos1.png 


\section{INFORMATION ARTIFACTS AND MEDICATION-TAKING STRATEGIES}

It was observed that the visual elements are always present in the medication-taking process (Correr \& Otuki, 2013; Sadowski, 2011; Waarde, 2005). The visual elements are mainly used to identify, recognize and differentiate medicines. They are also an important part of the decision to take medicine, that is, which to take. Several pharmacists have reported adopting strategies involving the use of color-coded drawings, pictures, envelopes, or stickers to guide the elderly in the use of their medications.

Werlang, Argimon and Stein (2008) recall the importance of the elderly to pursue their own strategies. It is necessary to consider that "regardless of the internal or external nature of the strategy to be chosen, when people seek these tools on their own, they are more motivated to use them, becoming more convinced of their effectiveness" (Werlang, Argimon, Stein, 2008, p. 98). According to the authors, the elderly become more motivated to use them and this can be observed as one of the results of the interviews. Thus, personalizing information is important to aid the elderly in able to adhere to their treatment.

Even with regard to memory, two questions must be presented. The first one refers to the fact that the process of memorization for taking medications includes medical prescription. In a study conducted by Silva (2017) on the use of medicines by elderly patients in Brazil, most participants stated that they first memorize the medicine prescription and then use visual characteristics/ elements of the medicine packaging, such as color, shape (carton, blister) and size, to remember which medicine they should take and when. Accordingly, regulated artifacts are used as external memory strategy to take medicines by elderly.

Another relevant aspect is the role of the medicine itself as an information artifact. Practically all the elderly interviewed use the color, size or shape of the medication as a visual element to aid their medication intake.

However, when memory declines in elderly patients, non-regulated artifacts are adopted by to aid remembering the therapeutic regimen whether created by the elderly, by pharmacist or by friends/family. It was observed that the complexity of the use and structuring of the visual elements increases according to the complexity of the therapeutic regimen, in order to guarantee that the visual information is sufficient for the correct taking of the medicines. It can be observed the use of more than one strategy, evidencing itself more used according to the research of Boron, Rogers and Fisk (2013): location, visibility, association and pill holder.

The strategy for taking medicines can also be developed by the elderly themselves. An example of this is a simple and effective strategy adopted by an elderly woman to take her pills In the morning, afternoon, and evening (Silva, 2017). 
Some pills should be taken once a day, others twice and three times a day. Her strategy was to cut the pilss' blister from a coding developed by her, to identify the tablets that should be taken in the morning (once a day), morning and afternoon (twice a day) and morning, afternoon and evening (three times a day). Figure 21 illustrates the customization developed by the elderly woman. The elderly woman did not create any new information artifacts, but she intervened in the blister that she already received with the medicines.
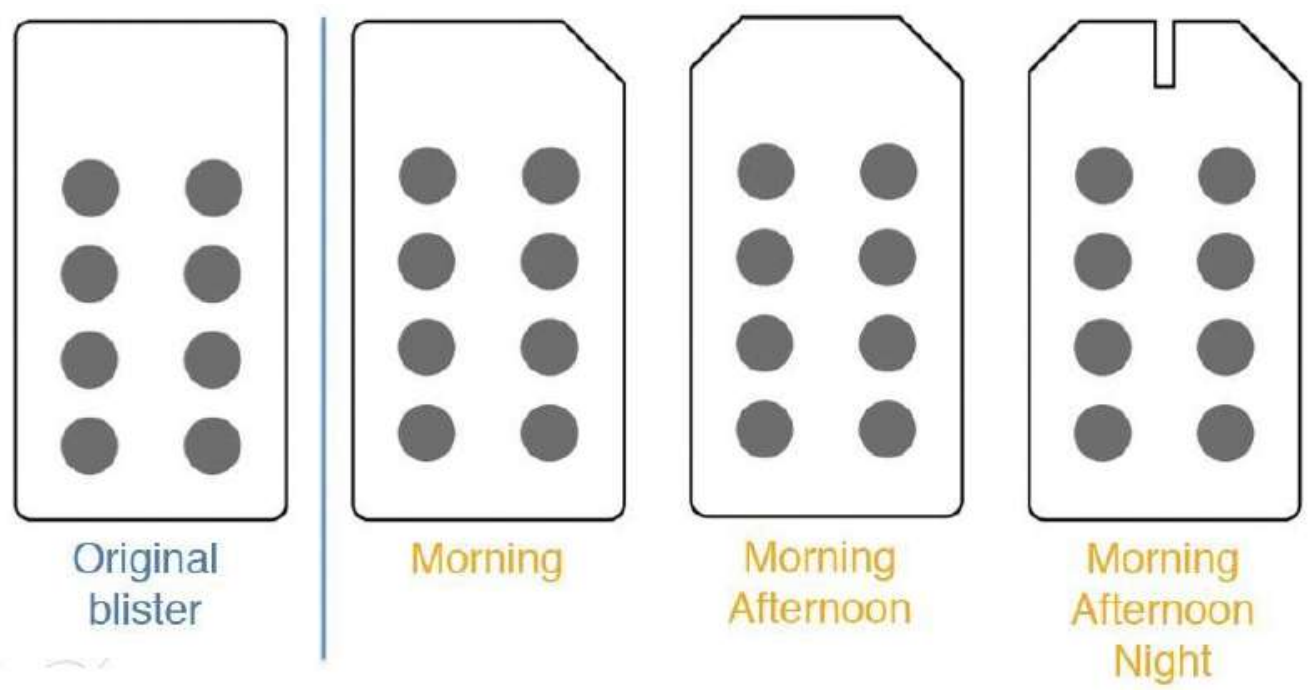

Figure 21: Cutting the blister to identify how much and when to take the medicine. Source: Developted by the author (2017)

The development of these various types of medication information artifacts is a way to make the artifact personal so that it works specifically for that person and his or her context, especially for polymedicated elderly people.

It is evident that the strategies they found are the result of several attempts in order not only to take the medication correctly, but also to make everyday life easier. When it becomes difficult, it has been observed in some interviewees' statements that the rigor becomes smaller. One respondent commented that her husband decided to take all the medications at one time in the morning, contrary to the prescription he had received from the doctors. It was easier that way.

One of the elderly interviewed looked for in technology a way to correctly take their medicines, that is, of "managing the medication", term that he used. He programmed alarms for the hours but reported that several times he turned the alarm off without taking the medicine and ended up forgetting. Posting re- 
minders or medical prescription in the refrigerator is a common practice among seniors as well as highlighting the relevant information in the prescription.

The oblivion, a point repeatedly reported in the literature (Who, 2003; Werlang, Argimon, \& Stein, 2008; Insel et al, 2013), was also reported by some elderly people. By being away from home, or involved in many activities at home, they eventually forget to take the medications. On the other hand, most of the elderly reported that they memorize what they have to take. One of the participants, who previously remembered the medicines well, said he is now having trouble remembering and thinks about looking for some other strategy to help take the medicine correctly. In summary, it was observed that the elderly used memorization associated to the verification of the medication (color, size, shape) and location (where they are left) associated with events of their daily life. It should also be noted that memory strategies should vary with regard to where the elderly are (at home, at work, on the road, on the road). The grouping of the medicines, either in their original packaging, in blisters or individually (outside their packaging) also characterized several reports. They are grouped by schedule, usually in the morning, lunch, afternoon and evening, in plastic boxes and baskets (Figure 22) when the elderly are at home. When they go out to work or travel, it is common to use bags or pill holders.

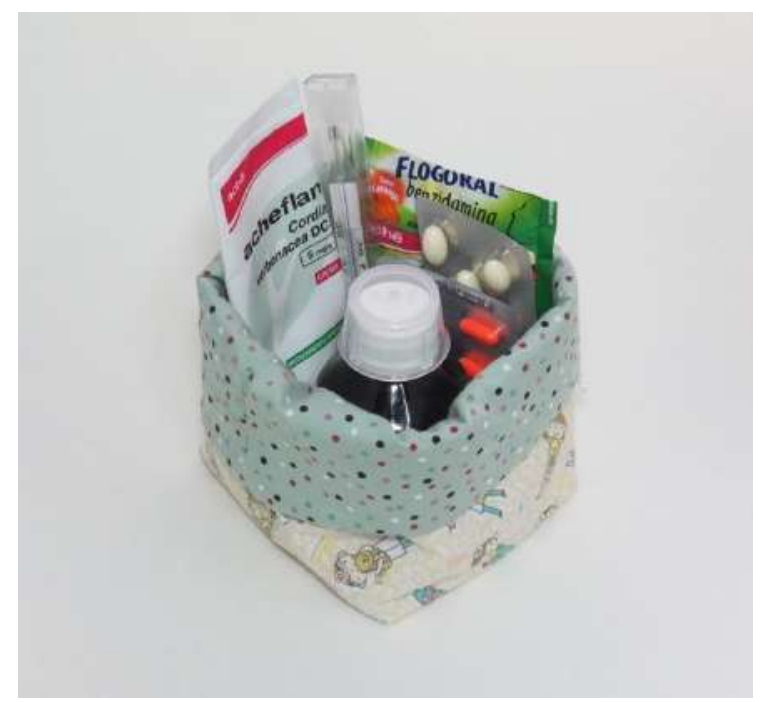

Figure 22 - Example of container for storage medicaments. Source: https://img.elo7. com.br/product/zoom/20125Co/cesta-necessaire-farmacinha-remedio.jpg 
Table 3 shows the main memory strategies, identified in Silva's study (Silva, 2017), used by elderly patients to remember.

\begin{tabular}{|l|l|}
\hline Internal & External \\
\hline Tie to other life events & Calendar notes \\
\hline & Photographs \\
\hline & Putting something in a special place \\
\hline & Reminder notes \\
\hline & Timer \\
\hline
\end{tabular}

Table 3 - The main memory strategies used by elderly patients to remember. Source: the author.

In relation to medication adherence strategies described by Boron, Rogers and Fisk (2013, p. 13), the following strategies were identified: Pill Caddy, Association, External Reminder, Location and Visibility. The use of prospective memory was evident among the elderly (Werlang, Argimon \& Stein, 2008; Insel et al, 2013) and the visual elements serve as clues to start the planned action.

\section{FINAL CONSIDERATIONS}

TThe task of taking medications is complex, particularly for elderly who need to take many medications on a daily basis. Articulating information to create your drug use strategies is a challenge, especially because these strategies should ensure that they remember which medication to take and have also been taken properly. Information artifacts add to the process of memorizing - which is a kind of internal memory aid - insofar as they are visual clues to activate memory. Both regulated and unregulated artifacts can be considered in drug use strategies. Of the regulated artifacts, the package leaflet is the least used either for its informational complexity (technical information) or for its visual appearance (large volume of text, few Principles of Information Design applied). However, the regulation of these artifacts presents a challenge for designers, since it limits their interference in the sense of making them more efficient as cognitive artifacts of information directed to the use of medication by the elderly. The designers can discuss them, propose suggestions and influence the legislation, as was the case of the magisterial leaflets of Paraná.

As far as unregulated artifacts are concerned, a good part of those that are marketed present problems related to visual information as well as those that are developed by the elderly themselves, friends or relatives. Pharmacists also face difficulties in designing artifacts to guide the elderly in taking medications. Here the challenge for designers lies in the clear understanding of the task of taking 
medications by the elderly, as well as their particularity for each elderly person relating memory and visual elements.

In any case, they are topics that deserve more in-depth studies and constitute a fertile ground for research in Information Design.

\section{ACKNOWLEDGMENTS}

Thanks are due to CAPES, agency of the Ministry of Education of Brazil for the improvement of higher education, for awarding a grant to the first author of this chapter to develop his doctoral research.

\section{REFERENCES}

Bernard, S. (2014). The Perfect Prescription - How the pill bottle was remade-sensibly and beautifully. In: Home: New York Best Doctors. <http://nymag.com/nymetro/health/features/11700/index1.html>, 04/12/2014

Boron, J. B.; Rogers, W. A. \& Fisk, A. D. (2013). Everyday memory strategies for medication adherence. Geriatric Nursing 34: pp. 395-401

Bouazzaoui, B.; Isingrini, M.; Fay, S.; Angel, L.; Vanneste, S.; Clarys, D. \& Taconnat, L. (2010). Aging and self-reported internal and external memory strategy uses: The role of executive functioning. Acta Psychologica 135: pp. 59-66

Brasil. (2014). Ministério da Saúde. Secretaria de Ciência, Tecnologia e Insumos Estratégicos. Departamento de Assistência Farmacêutica e Insumos Estratégicos. Capacitação para implantação dos serviços de clínica farmacêutica. Brasília: Ministério da Saúde.

Brasil. (2014a). Ministério da Saúde. Secretaria de Ciência, Tecnologia e Insumos Estratégicos. Departamento de Assistência Farmacêutica e Insumos Estratégicos. Serviços farmacêuticos na atenção básica à saúde. Brasília: Ministério da Saúde.

Brasil. (2014b). Ministério da Saúde. Manual de Embalagens de Medicamentos. Brasília: Ministério da Saúde

Brasil. (2010). Agência Nacional de Vigilância Sanitária. O que devemos saber sobre medicamentos. Brasília: Anvisa.

Brasil. (2001). Resolução - RDC no 47 de 28 de março de 2001. In: Home: ANVISA < http://www.anvisa.gov.br/hotsite/genericos/legis/resolucoes/47_01rdc.htm>. 23/01/2017

Correr, C. J. \& Otuki, M. F. (2013). A prática farmacêutica na farmácia comunitária. Porto Alegre: Artmed.

Dervin, B.; Foreman-Vernet, L.; \& Lauterbach, E. (2003). Sense-Making Methodology Reader - Selected Writings of Brenda Dervin. New Jersey: Hampton Press.

Dixon-Woods, M. (2001). Writing wrongs? An analysis of published discourses about 
the use of patient information leaflets. Social Science \& Medicine 52: pp. 1417-1432

Heersmink, R. (2013). A Taxonomy of Cognitive Artifacts: Function, Information, and Categories. Rev.Phil.Psych. 4: 465-481.

Insel, K. C.; Einstein, G. O.; Morrow, D. G. \& Hepworth, J T. (2013). A multifaceted prospective memory intervention to improve medication adherence: Design of a randomized control trial. Contemporary Clinical Trials, 34: pp. 45-52

Kristiansson, M. (2011). Memory, aging and external memory aids: Two traditions of cognitive research and their implications for a successful development of memory augmentation. Master's Thesis in Cognitive Science. Department of Computer and Information Science Linköping University.

Leite, R. A. F. \& Ventura, C. A. A. (2011). Direito à Informação em Saúde: acesso a informações sobre diagnóstico, exames, medicamentos, riscos e benefícios do tratamento. XXIV Congresso Brasileiro de Biblioteconomia, Documentação e Ciência da Informação. Sistemas de Informação, Multiculturalidade e Inclusão Social. Maceió, Alagoas. In: Dossiê Aids Brasil. <http://dabrasil.weebly.com/uploads/6/3/3/0/6330657/ direito__informao_em_sade.pdf>,17/09/2014.

Minas Gerais. (2009). Linha Guia do Cuidado Farmacêutico. Rede Farmácia de Minas. Uma estratégia para promover o uso racional de medicamentos e a farmacovigilância no SUS. Belo Horizonte.

O'grady, J. \& O'grady, K. V. (2008). The Information Design Handbook. How Books: Cincinatti, Ohio.

Paraná. (2013). Resolução SESA No.062/2013. In: Home: Secretaria da Saúde - Governo do Estado do Paraná. < http://www.saude.pr.gov.br/arquivos/File/RESOLUCOES2012/Resolucao0622013.pdf>, 19/11/2015.

Sadowski, C. A. (2011). Providing health information to older adults. Reviews in Clinical Gerontology, 55-66.

São Paulo. (1999). LEI No 10.241, DE 17 DE MARÇO DE 1999. In: Home: Câmara dos Deputados. <http://www.camara.gov.br/sileg/integras/224907.pdf>, 02/07/2014.

Silva, C. H. (2017). Framework conceitual sobre uso múltiplos medicamentos por idosos autônomos com elementos visuais de ajuda. 2017. 211 f. Tese (Doutorado) - Setor de Artes, Comunicação e Design da Universidade Federal do Paraná, UFPR, Curitiba.

Spinillo, C. \& Waarde, K. (2013). Pictorial instructions in package inserts of Brazil and European Union: Are they for patients? In: FADEL, L. M.; SPINILLO, C. G.; MOURA, M. \& TRISKA, R. (Org.). Selected Readings of the Information Design International Conference 2012. Florianópolis: SBDI, 119-120.

Vieira, L.B. (2013). Avaliação da adesão à terapêutica de pacientes idosos hipertensos antes e após o desenvolvimento e uso de um Sistema Eletrônico de Uso Personalizado e Controlado de Medicamentos. 2013. 125 f. Tese (Doutorado) - Escola de Enfermagem de Ribeirão Preto, USP, Ribeirão Preto.

Zogg, J. B.; Woods, S. P.; Sauceda, J. A.; Wiebe, J. S. \& Simoni, J. M. (2012). The role of prospective memory in medication adherence: a review of an emerging literature. J 
Behav Med., 35: pp. 47-62

Werlang, M. C.; Argimon, I. I. L.; Stein, L. M. (2008). Estratégias de Memória utilizadas por idosos para lembrarem do uso dos seus medicamentos. Estud. Interdiscip. Envelhec., Porto Alegre, v. 13, n. 1, pp. 95-115.

Waarde, K. (2014). Information about medicines for patients in Europe: to impede or to empower. In: Design, User Experience, and Usability: User Experience Design for Everyday Life Applications and Services: Third International Conference, DUXU 2014, Held as Part of HCI International 2014, Heraklion, Crete, Greece, June 22-27, 2014, Proceedings, Part 3.

Waarde, K. (2013). Designing information about medicines: The role of visual design. In: Fadel, L. M.; Spinillo, C. G.; Moura, M. \& Triska, R. (Org.). Selected Readings of the Information Design International Conference 2012. Florianópolis: SBDI, p. pp. 106118,120 .

Waarde, K. (2010). Visual Communication for medicines: malignant assumptions and benign Design? Visible Language 44.1 Special Issue: Communication Design Failures. Waarde, K. (2005). An information design approach to labelling. Design Research. 